\title{
Plant defense response against Fusarium oxysporum and strategies to develop tolerant genotypes in banana
}

\author{
V. Swarupa $\cdot$ K. V. Ravishankar $\cdot$ A. Rekha
}

Received: 25 October 2013 / Accepted: 30 December 2013 / Published online: 14 January 2014

(C) Springer-Verlag Berlin Heidelberg 2014

\begin{abstract}
Soil-borne fungal pathogen, Fusarium oxysporum causes major economic losses by inducing necrosis and wilting symptoms in many crop plants. Management of fusarium wilt is achieved mainly by the use of chemical fungicides which affect the soil health and their efficiency is often limited by pathogenic variability. Hence understanding the nature of interaction between pathogen and host may help to select and improve better cultivars. Current research evidences highlight the role of oxidative burst and antioxidant enzymes indicating that ROS act as an important signaling molecule in banana defense response against Fusarium oxysporum f.sp. cubense. The role of jasmonic acid signaling in plant defense against necrotrophic pathogens is well recognized. But recent studies show that the role of salicylic acid is complex and ambiguous against necrotrophic pathogens like Fusarium oxysporum, leading to many intriguing questions about its relationship between other signaling compounds. In case of banana, a major challenge is to identify specific receptors for effector proteins like SIX proteins and also the components of various signal transduction pathways. Significant progress has been made to uncover the role of defense genes but is limited to only model plants such as Arabidopsis and tomato. Keeping this in view, we review the host response, pathogen diversity, current understanding of biochemical and molecular changes that occur during host and pathogen interaction. Developing resistant cultivars through mutation,
\end{abstract}

V. Swarupa $\cdot$ K. V. Ravishankar $(\bowtie)$

Division of Biotechnology, Indian Institute of Horticultural

Research, Hesaraghatta Lake Post, Bengaluru 560089, India

e-mail: kvravi@iihr.ernet.in; kv_ravishankar@yahoo.co.in

A. Rekha

Division of Fruit Crops, Indian Institute of Horticultural

Research, Hesaraghatta Lake Post, Bengaluru 560089, India breeding, transgenic and cisgenic approaches have been discussed. This would help us to understand host defenses against Fusarium oxysporum and to formulate strategies to develop tolerant cultivars.

Keywords Fusarium wilt - Oxidative burst $\cdot$ Signal transduction · Tolerance mechanism

\section{Introduction}

Banana which is rich in nutritional source is the major food crop for millions of people and is an important export commodity crop of many countries. India is the major producer in the world. Recently, whole genome of banana has been sequenced. D'Hont et al. (2012) have sequenced the 523 Megabase $(\mathrm{Mb})$ genome of DH-Pahang, a doubled haploid $M$. acuminata genotype $(2 n=22)$ and identified 36,542 protein-coding gene models. This would help us in better understanding of genetics of many agronomic traits. Fusarium wilt disease is the major threat to not only banana production, but to more than 100 species of plants (Berrocal-Lobo and Molina 2007) which is caused by soilborne asexual fungus Fusarium oxysporum (Fox). Some strains of Fusarium live as non-pathogenic populations also. Based on the species they are subdivided into formae specialis (f.sp). For example, fungus causing disease of banana is named as Fusarium oxysporum f.sp. cubense $(F o c)$. It invades the xylem vessels resulting in wilting and death of the plant. Fusarium oxysporum f.sp. lycopersici (Fol) which infects tomato has a bigger genome size of 69 mega bases containing 15 chromosomes with 17,735 coding sequences compared to other Fusarium species such as $F$. graminearum (with $42 \mathrm{Mb}$ ) and $F$. verticillioides (with $36 \mathrm{Mb}$ ) (Ma et al. 2010). 
Fusarium wilt of banana was first recognized in Australia in 1874 (Bancroft 1876). Based on the pathogenicity to specific banana cultivars, $F o c$ has been classified into four races. Race 1, virulent to AAA genomic cultivar 'Gros Michel' and $A A B$ Rasthali; race 2, virulent to 'Bluggoe' of the ABB genomic group; and race 4 virulent to 'AAA Cavendish'; race 3 , which do not affect banana are considered as distinct forma specialis, heliconiae. Fox has remarkably broad host range, infecting both monocotyledonous and dicotyledonous plants (Ma et al. 2010). For example, eight pathogenic races in chickpea (Jimenez-Gasco et al. 2004), and four pathogenic races in melon (Zvirin et al. 2010), etc., were identified, which represent the diverse nature of Fox.

The disease is prevalent in all the banana-growing regions except Papua New Guinea, the South Pacific Islands and some of the countries bordering the Mediterranean. Fusarium wilt is a serious problem on many banana cultivars grown by small holders for local consumption which include various regions such as Philippines, Brazil, Malaysia, India, Australia, East Africa, etc. (Moore et al. 1995). The recent incidence of Foc is reported in various parts like in Indonesia (Hermanto et al. 2011); in India which is now widespread and destructive in almost all the bananas growing states (Mustaffa and Thangavelu 2011); confirmation of Fusarium oxysporum f.sp. cubense tropical race 4 (TR 4) in the Philippines (Molina et al. 2008). A recent outbreak of fusarium wilt in Jordan and Mozambique raised apprehension it could spread to Latin America in future (Butler 2013). This is of a great concern to the banana industry.

Genetic diversity of $F o c$ is classified based on vegetative compatibility grouping (VCG), i.e., isolates belonging to same VCG possess similar or identical genetic makeup. Phylogenetically diverse formae specialis of Fox are increasing in recent times (Ploetz 2005). Several DNA-based techniques have been used to analyze the worldwide population of Fox. Classifying Fusarium is always difficult but a FUSARIUM ID v. 1.0, a publicly available database based on partial translation elongation factor 1 alpha (TEF) DNA sequences, which can be used as a phylogenetic marker has been created (Geiser et al. 2004). The recent development in the molecular discrimination of Fox was reviewed by Lievens et al. (2008). Recently few studies have demonstrated the efficient use of markers to detect and assess the genetic diversity of Foc (Dita et al. 2010; Groenewald et al. 2006; Ingle and Ingle 2013; Leong et al. 2010; Li et al. 2011a). These markers-based tools help in providing rapid and reliable detection and monitoring of Foc isolates.

Foc strains represent many other unrelated lineages of Fox; hence, new forms of Fox may be derived from other pathogenic and non-pathogenic members of the species. They also, undergo frequent mutations (Fourie et al. 2009). These recent reports signal the need for understanding evolution of Fusarium strains which would help in developing strategies to combat disease. Here, we review the underlying defense mechanisms of plant to Fox, with a focus on the monocot crop banana.

\section{Mechanism of infection}

Spores of Foc which persists in the soil for a very long duration germinate and grow toward the nearby roots of host banana plants. Initial infection occurs in root hairs, proceeds to the larger roots and via cortex reaches xylem vessels (Perez-Vicente 2004; Ploetz 2005). Mycelium branches and produces microconidia, which germinates and penetrates through the perforations of xylem into adjoining vessels and proceeds with the infection. The plant produces gels and tyloses as a defense mechanism to prevent infection and entering to the rhizome which results in blockage and shortage of water supply to stem and leaves.

Recently developed technique of transforming the plasmid containing GFP (green fluorescent protein) into Fusarium oxysporum helps to visualize and analyze the colonization and infection processes in vivo with the help of confocal microscopy. Using (GFP)-tagged transformants of Foc race 4, Li et al. (2011b) have reported that Foc race 4 was capable of invading the epidermal cells of banana roots directly and in banana roots, fungal hyphae were able to penetrate cell walls directly to grow inside and outside cells. In another study, Li et al. (2013a) group has monitored the infection process of both GFP-expressing Foc 1 (race 1 of Fusarium oxysporum) and Foc TR4 and reported that both were found to be able to invade banana roots and later spread to root vascular tissues.

After infection, the first internal symptom that is observed is the development of a reddish brown discoloration of the xylem in fine or smaller non-woody roots (feeder roots) at the sites of infection. Vascular discoloration progresses to the rhizome and ultimately proceeds up to pseudostem. External symptoms due to shortage of water supply to the leaves are the yellowing of leaves starting from the older to younger leaves leading to complete wilting and death of leaves. It is difficult to control disease because the pathogen spreads through the surface water, plant material and through implements and machinery. In the infected soil, the pathogen persists by colonizing on non-susceptible hosts and produce chlamydospores which act as reservoirs of inoculums (Schippers and Van Eck 1981).

\section{Molecular aspects of host defense}

Despite decades of conventional breeding and selection of resistant cultivars, due to the evolution of different lineages 
Table 1 Candidate genes identified against Fusarium oxysporum in crop plants

\begin{tabular}{|c|c|c|}
\hline Candidate genes & Crop & References \\
\hline \multicolumn{3}{|l|}{ R genes } \\
\hline RFO1, RFO2, RFO3, RFO4, RFO6 & Arabidopsis & Diener and Ausubel (2005) \\
\hline Fom2 & Melon & Joobeur et al. (2004) \\
\hline II & Tomato & Houterman et al. (2008) \\
\hline$I 2$ & Tomato & Berrocal-Lobo and Molina (2007) \\
\hline 13 & Tomato & Rep et al. (2004) \\
\hline \multicolumn{3}{|l|}{ Pathogenesis related proteins } \\
\hline Defensin & Tomato & Abdallah et al. (2010) \\
\hline Chitinase & Tomato & Jongedijk et al. (1995) \\
\hline Thaumatin & Banana & Mahdavi et al. (2012) \\
\hline$\beta-1,3$ glucanase & Banana & Maziah et al. (2007) \\
\hline NPR1 & Banana & Endah et al. (2008) \\
\hline \multicolumn{3}{|l|}{ Antimicrobial activity } \\
\hline Thi2.1 & Arabidopsis & Epple et al. (1997) \\
\hline Polyphenol oxidase & Banana & Kavino et al. (2007) \\
\hline CaAMP1 & Pepper & Lee et al. (2008) \\
\hline \multicolumn{3}{|l|}{ Cell wall strengthening } \\
\hline Phenylalanine ammonia lyase & Banana & Van den berg et al. (2007) \\
\hline Peroxidase & Banana & De Ascensao and Dubery (2003) \\
\hline Polygalacturonase inhibitor protein & Tomato & Salehzadeh (2012) \\
\hline \multicolumn{3}{|l|}{ Antioxidants } \\
\hline NADPH oxidase & Arabidopsis & Zhu et al. (2013) \\
\hline Ascorbate peroxidase & Chickpea & Garcia-Limones et al. (2009) \\
\hline Catalase & Tomato & Farag Hanaa et al. (2011) \\
\hline Superoxide dismutase & Banana & Li et al. (2011c) \\
\hline Glutathione- $S$-transferase & Tomato, Melon & Bolter et al. (1993) \\
\hline
\end{tabular}

of virulent races of Fox, it is not possible to control the disease. Hence, many studies are being focused toward genomic approaches to identify and understand the genes and their role in the defense response mechanism. The knowledge generated would help in crop improvement in future. Complex sets of genes that help in recognition and signal transduction which leads to defense response have been identified. The major candidate genes against fusarium wilt, identified in many crops are listed in Table 1.

\section{Plant recognition}

Plants respond immediately after the pathogen infection either to hinder it completely (resistant plants) or to minimize the effect of pathogen effects (tolerant plants). But when the pathogen succeeds, it leads to disease (susceptible). The basis of resistance and susceptibility in plantpathogen systems depends on many defense functions induced during interaction, which varies with the host and the pathogen. In this process, rapid recognition of a potential invader is a prerequisite for the initiation of an efficient defense response. This is achieved through the recognition of specific pathogen- or plant cell wall-derived signal molecules, termed exogenous or endogenous elicitors, respectively. Most studied recognition proteins are pathogen recognition receptors (PRRs), which are cell surface receptors and resistance genes (R-genes). Some of these are characterized as cell-surface receptors but most of them are cytoplasmic proteins of the nucleotide-binding leucinerich repeats. PRRs detect conserved microbial molecules referred to as "microbe-associated molecular patterns" (MAMPs), to activate MAMP-triggered immunity (MTI). Successful pathogens overcome MTI by secreting effectors which nullify the effect of complementary molecular targets in the host cell. Plants in turn are evolved to defend with the help of other proteins called resistance proteins that activate inducible effector triggered immunity (ETI). Recognition of the pathogen and elicitation of defense response by the host is briefly depicted in Fig. 1 .

Plant's perception of the pathogen was clearly explained by the hypothesis called Gene-for-Gene (GFG) hypothesis (Dangl and Jones 2001; Deslandes et al. 2003). This GFG concept was supported by extensive experimental data which characterizes the interaction of the plant's $R$ gene and the pathogen's cognate $a v r$ gene, in a receptor-ligand 
Fig. 1 Recognition of the pathogen and elicitation of defense response by the host. When the pathogen attacks the host through their typical molecular signatures called microbeassociated molecular patterns (MAMPs) and/or effectors, they are recognized by the host through specific pathogen recognition receptors (PRRs) and R-genes leading to host defense response via the activation of multiple signal transduction pathways such as salicylic acid (SA), jasmonic acid (JA) and ethylene. Pathogen recognition results in change in membrane potential leading to activation of NADPH complex that results in production of reactive oxygen species (ROS), which acts as major signaling molecules and in turn, may induce other signaling molecules. Change in ion flux also induces $\mathrm{Ca}^{2+}$ signaling. Defense responses against MAMPs are called pathogen-triggered immunity (PTI) and against effectors are called effector-triggered immunity (ETI)

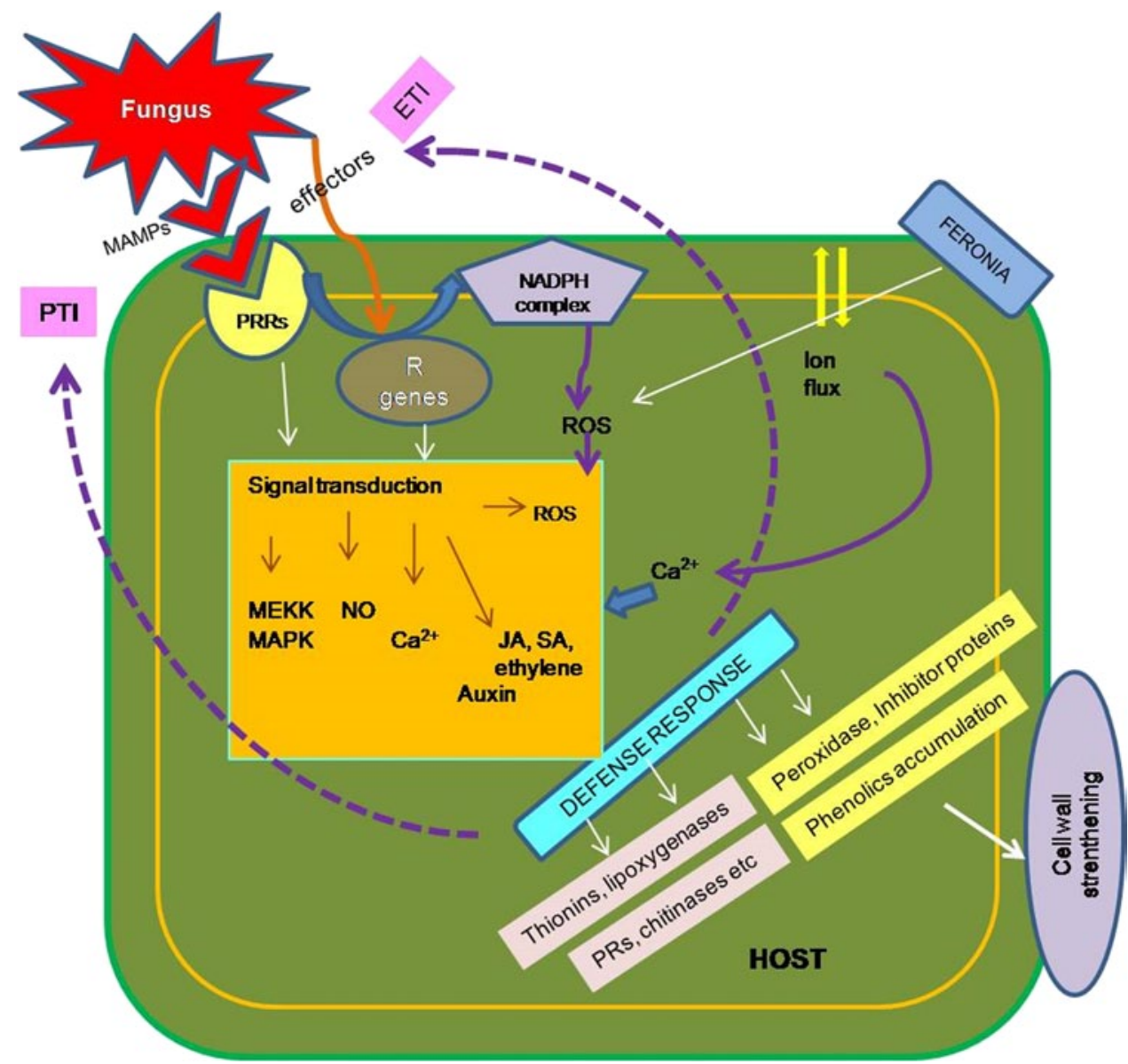

fashion. Another hypothesis proposed by recent studies called guard hypothesis does not involve direct interaction as in GFG model. This model describes the interaction between 'guardee' (guarded by $R$ gene) and its corresponding avr/avr induced effectors. Absence of guarding $\mathrm{R}$ gene favors the pathogen in susceptible plants, whereas presence of $\mathrm{R}$ genes in resistant plants leads to innate immunity. The classic example is the $I$ gene-mediated resistance against effector protein SIX (secreted in xylem) secreted by Fol. In tomato, six $I$ loci ( $I$ for immunity) which are R-genes, called $I$ genes against the wilt-inducing $\mathrm{Fol}$ were identified conferring resistance to different $\mathrm{Fol}$ races and some of them have been found to encode resistance proteins of the NBS-LRR subclass. The resistance mediated by the I-3 gene seems to rely on the recognition of effector protein SIX1, indicating SIX1 could be the corresponding Avr protein (Berrocal-Lobo and Molina 2007). Six dominant resistance loci to Fox f.sp. matthiolae (RFO) were identified in the Arabidopsis Col-0 accession (Diener and Ausubel 2005). It was found that expression of RFO3 (receptorlike kinase gene) is highest in vascular tissue and restricts Fusarium oxysporum f.sp. matthioli (Fom) infection and confers resistance but provides no resistance to two other crucifer-infecting $F$. oxysporum pathogens. This suggests that diversity in RLK PRRs (Receptor-like kinase (RLK) pathogen recognition receptors (PRRs)) is a major determinant of quantitative resistance (Cole and Diener 2013). Seventy-four immunity related gene candidates (IRGs) containing typical R-gene structure were identified in Cape gooseberry (Physalis peruviana). Screening and characterization of 14 Fox resistance and susceptible genotypes using those IRG specific primers has allowed to detect one SNP at the PpIRG-63 marker revealing non-synonymous mutation in the predicted LRR domain, suggesting functional roles for resistance (Enciso-Rodriguez et al. 2013).

Among defense-related genes, those encoding nucleotide-binding site leucine-rich repeat proteins were found to be less represented in the Musa sequence ( 89 genes) compared to Oryza sativa (464 genes) and Vitis vinifera (459 genes) (D'Hont et al. 2012). In banana an extensive isolation of resistance genes has been done (Miller et al. 2008; Peraza-Echeverria et al. 2008). PTI (pathogen-triggered immunity)-related genes like chitin elicitor-binding protein (CEBiP) and the chitin elicitor receptor kinase (CERK1), important components of the plant signaling pathway that recognizes chitin oligosaccharide, are expressed more in resistant cultivar than susceptible against Foc TR4 (Li et al. 2012). Also in their study they have discussed about 
the expression of resistance protein complex called RIN4/ RPM1, which helps to trigger disease resistance.

In general, the recognition triggers a resistance response accompanied by rapid cell death of the infected cells called hypersensitive response (HR) leading to limited cell death of neighboring cells. Impact of HR depends on the lifestyle of the pathogen. Biotrophic pathogens need living host cells for its development. Therefore, death of the infected cells could deprive the pathogen of nutrients and helps in resistance. But necrotrophic pathogens often trigger nutrient leakage from the host cells and are able to survive from dead tissues. Cell death occurrence during susceptible host-pathogen interactions in which pathogens can multiply in their hosts is common. Many virulent pathogens induce cell death with apoptotic features (Yao et al. 2002).

Thus, the role of host cell death, leads to confusion, but the studies suggest that HR may simply be the consequence of simultaneous activation of cell death and defense response pathways like systemic acquired resistance (SAR). This cell death and the associated cellular decompartmentalization could induce the release of toxic compounds (phytoalexins) and might inhibit the pathogen entry. Hence HR is not always necessary for resistance (Fraser 1990; Wolter et al. 1993) but coordination between the different induced mechanisms is required for successful resistance. Cell death during plant-pathogen interactions may be important for robust resistance as well as susceptibility depending on the lifestyle of the pathogen. Also resistance and susceptibility are determined by various other mechanisms induced during host-pathogen interaction.

\section{Biochemical changes}

Plants have developed an array of defense response mechanisms against pathogen attack, among them, physiological and biochemical changes associated with fungal diseases in the host are widely studied. In general, when the pathogen attacks the host, the initial step would be the recognition of specific pathogen strains, leading to activation of defense signaling networks. The responses are usually associated with a rapid and transient production of reactive oxygen species (ROS) such as the superoxide anion radical $\left(\mathrm{O}_{2}^{-}\right)$, hydroxyl radical $(\cdot \mathrm{OH})$ and hydrogen peroxide $\left(\mathrm{H}_{2} \mathrm{O}_{2}\right)$. In turn ROS should be detoxified efficiently otherwise may lead to cell damage. This is done by, various ROS-scavenging systems, including ascorbate peroxidases, glutathione, superoxide dismutases, and catalases. These enzymes maintain ROS homeostasis in different compartments of the plant cell (Mittler et al. 2004). Also various studies have reported that ROS scavenging enzymes can be used as a biochemical marker for Foc resistance in banana (Kavino et al. 2007; Li et al. 2011c).
Cell wall strengthening through structurally and chemically act as an important resistance response against fungi. Accumulation of phenolic acids which are the monomers of lignin (cell wall thickening) and induction of fungal cell wall degrading enzymes (CWDEs) helps to inhibit pathogen entry. Soluble and cell wall-bound phenolics accumulate in plant tissue challenged by fungal pathogens (Huckelhoven 2007). Often these transcripts and proteins are induced during a susceptible as well as a resistant interaction, but the timing and abundance differentiate resistance and susceptibility. Lignification makes the cell wall more resistant to mechanical pressure applied during penetration by the fungal appressoria (Bechinger et al. 1999). Lignins possibly contribute to the effective and timely production of papillae and gels in response to Foc. Recent studies on proteomic analysis of Foc4 infected banana roots have revealed the differential expression of various defense related proteins, majority of them are PR proteins; reactive oxygen species and scavenging and cell-wall strengthening genes describing their association with resistance in banana (Li et al. 2013b; Lu et al. 2013).

In the tolerant genotype of banana (GCTCV 218), the induction of biochemical defense was very early against Foc race 4, by upregulating cell wall strengthening enzymes such as peroxidase and phenyl alanine ammonia lyase and by accumulating cell-wall bound phenolic content (Van den Berg et al. 2007). Increased flux through the phenylpropanoid pathway in Foc race 4 infected, Musa acuminata roots of Grand Naine resulted in the synthesis of cinnamic acid and benzoic acid derivatives (De Ascensao and Dubery 2003). The possible role of beta-1, 3-glucanase against fusarium wilt of banana was explained by Jin et al. (2007). The induction of peroxidase and $\alpha-1,3$-glucanase activities in F. oxysporum-infected tomato roots of resistant cultivar over their uninfected check was reported by Mohamed et al. (2007). For cell wall strengthening various other inhibitor proteins such as xylanase inhibitor protein (XIP), polygalacturonase inhibitor protein (PGIP), etc. also plays a role by inhibiting the plant cell wall degrading enzymes secreted by fungus. PGIPs play a role in defense against pathogenic fungi (Di et al. 2006; De Lorenzo et al. 2001) by inhibiting polygalacturonases secreted by fungi. The role of PGIP against fusarium wilt tolerance in banana was discussed by Ravishankar et al. (2011).

Because of lack of water supply to the leaves during infection, the other processes like, photosynthetic rate, stomatal conductance, transpiration rate and water potential were observed to be altered in banana (Dong et al. 2012). The free amino acid content was also found to decrease with increase in fusarium wilt infection (Rathod and Vakharia 2011). During stress, a change in metabolic process is commonly observed. Studying specific changes in a particular crop would help to screen and differentiate 
the genotypes. Based on studies till date, we can conclude that initial recognition leads to PTI responses mainly like oxidative burst and cell wall lignifications in banana. Foc being necrotroph pathogen it can be hypothesized that the deregulation of pathogen induced cell death may lead to susceptibility. But information on other factors like protease inhibitors which inhibit cell wall degrading enzymes (CWDEs) associated with resistance mechanism needs to be generated. Recent studies have revealed that flavonoids and phenolics serve as a major biochemical marker against fungal infection (Clematis et al. 2011; Venkatesh Krishna et al. 2013). However, studies needs to be expanded toward the examination of such specific biochemical marker against fusarium wilt in banana.

\section{Signal transduction}

After perception of the pathogen, signal transduction pathways are activated to coordinate the plant defense mechanisms. Most of the experiments on mutant plants that are susceptible to pathogens have defective signal transduction pathways rather than in recognition. Hence, transcription factors or genes that are involved in signal transduction also play a major role in tolerance and susceptibility. For example, Thatcher et al. (2009) described that F. oxysporum hijacks coronatine insensitive 1 (COII)-mediated jasmonate signaling to promote the disease development in Arabidopsis. Genomic tools are now being used to uncover the complexity of the induced defense signaling networks that have evolved during the arms race between plants and pathogens (Pieterse and Dicke 2007). The identified genes that are affected by $F o x$ in different signaling pathways have been listed (Table 2) and discussed below.

\section{Reactive oxygen species}

Pathogen-associated molecular patterns (PAMPs) and effector-triggered immunity (ETI) are known to induce rapid production of ROS in an oxidative burst after infection with a pathogen, which is largely derived from the activity of membrane-localized NADPH oxidases (Torres et al. 2006). The foremost signaling molecule, ROS, induces various other downstream signaling molecules. ROS along with NO (nitric oxide) induce HR (hypersensitive response)-mediated cell death (Delledonne et al. 2001). ROS in association with salicylic acid are proposed to mediate the establishment of systemic defenses (Durrant and Dong 2004). The cytological studies have revealed that ROS and NO are associated with cell death adjacent to infected cells and so that both signals modulate each other's accumulation (Tada et al. 2004). Upregulation of NADPH oxidases was reported in the resistant banana cultivar in response to Foc (TR4) infection (Li et al. 2012). Oxidative burst is a better indicator of differential susceptibility of banana to Foc. Fusarium wilt tolerance is associated with early accumulation of $\mathrm{H}_{2} \mathrm{O}_{2}$ in roots ( $\mathrm{Li}$ et al. 2011c). Also Mandal et al. (2008) have discussed that in tomato oxidative burst serves as a weapon for the necrotroph pathogen, Fol. Early and higher expression of antioxidant enzymes such as peroxidase and glutaredoxin was identified, indicating oxidative burst as one of the possible tolerance mechanisms against fusarium wilt (Swarupa et al. 2013). Hence, emerging evidences suggest that oxidative burst (production of ROS) and ROS-detoxification mechanisms composed of ROS producing and antioxidant enzymes that helps in ROS homeostasis. Further ROS also serves as a major signaling molecule in banana defense response.

\section{Salicylic acid (SA), jasmonic acid (JA) and ethylene (ET)}

Most widely discussed three different defense plant signaling pathways are salicylic acid (SA), jasmonic acid (JA) and ethylene (ET) that modulate each other through a complex network of regulatory interactions based on different host-pathogen interactions (Kunkel and Brooks 2002).

The positive role of SA against biotrophic pathogens is known; however, its role on necrotrophs is still not clear. It was observed that the non-expression of pathogenesisrelated gene $1(N P R I)$ is an essential positive regulator of salicylic acid (SA)-induced pathogenesis-related (PR) gene expression and systemic acquired resistance (SAR). $M N P R 1 A$ and MNPRIB were isolated from banana and was reported that they were highly expressed after Foc infection (Endah et al. 2008). A week after the infection of tomato plants by Fol, daily spray of hormonal inducer (SA) for a week completely protected against fusarium wilt (Amel et al. 2010). The possible implication of SA in triggering date palm defense against its pathogen Fusarium oxysporum f.sp. albedinis (Foa) was confirmed by Dihazi et al. (2011). Even though, a few other studies also have reported that exogenous application of salicylic acid induces pathogenesis-related protein-1 and helps in defense response, however, recent studies have reported that internally SA loses its prominent role as a resistance response against necrotrophic pathogens like Fox but induces an effective defense response against biotrophic pathogens (Edgar et al. 2006; Li et al. 2012; Makandar et al. 2012).

The involvement of the SA was described recently: there was an absence of significant difference in expression of SA-related genes, whereas expression levels of genes that are involved in the JA biosynthesis such as, Lipoxygenase 
Table 2 Genes involved in signal transduction during Fox infection

\begin{tabular}{|c|c|c|}
\hline Candidate gene & Crop & References \\
\hline \multicolumn{3}{|l|}{ Salicylic acid } \\
\hline$N a h G$ & Arabidopsis & Berrocal-Lobo and Molina (2004) \\
\hline sid2-1 & Arabidopsis & Berrocal-Lobo and Molina (2004) \\
\hline eds5-1 & Arabidopsis & Berrocal-Lobo and Molina (2004) \\
\hline nprl-1 & Arabidopsis & Berrocal-Lobo and Molina (2004) \\
\hline pad4-1 & Arabidopsis & Berrocal-Lobo and Molina (2004) \\
\hline eds $1-1$ & Arabidopsis & Berrocal-Lobo and Molina (2004) \\
\hline$M N P R 1 A, M N P R 1 B$ & Banana & Endah et al. (2008) \\
\hline \multicolumn{3}{|l|}{ Jasmonic acid } \\
\hline col-1 & Tomato & Berrocal-Lobo and Molina (2004) \\
\hline jarl-1 & Tomato & Berrocal-Lobo and Molina (2004) \\
\hline $\mathrm{COII}$ & Arabidopsis & Thatcher et al. (2009) \\
\hline$L B D 20$ & Arabidopsis & Thatcher et al. (2012a) \\
\hline Lipoxygenase & Banana & Li et al. (2012) \\
\hline Allene oxide synthase & Banana & Li et al. (2012) \\
\hline \multicolumn{3}{|l|}{ Ethylene } \\
\hline ein2-5 & Tomato & Berrocal-Lobo and Molina (2007) \\
\hline EDS1 & Tomato & Berrocal-Lobo and Molina (2007) \\
\hline EIN3 & Banana & Li et al. (2012) \\
\hline EIL1 & Banana & Li et al. (2012) \\
\hline$E R F 1$ & Arabidopsis & Berrocal-Lobo and Molina (2004) \\
\hline$E R F 2$ & Arabidopsis & McGrath et al. (2005) \\
\hline ERF14 & Arabidopsis & Onate-Sanchez et al. (2007) \\
\hline \multicolumn{3}{|l|}{ G proteins } \\
\hline agb1-1, agb1-2, agg 1-1 and agg 1-2 & Arabidopsis & Perfus-Barbeoch et al. (2004), Trusov et al. (2009) \\
\hline \multicolumn{3}{|l|}{ ABA } \\
\hline$a b a 2-1$ & Arabidopsis & Anderson et al. (2004) \\
\hline$m y c 2$ & Arabidopsis & Anderson et al. (2004) \\
\hline \multicolumn{3}{|l|}{ Auxin } \\
\hline TIR1, AXR2, AXR3, AXR6, SGT1B, RING-BOX1 & Arabidopsis & Kidd et al. (2011) \\
\hline
\end{tabular}

(LOX)-like and Allene oxide synthase (AOS)-like and also the core JA-signaling components were found to be induced in the mutant resistant lines compared to a susceptible line of banana. Also for the ethylene signaling genes and transcription factors such as Ethylene Insensitive 3 (EIN3) and Ethylene Insensitive 3-like 1 (EIL1) were also induced which reports that resistance to the necrotrophic pathogen Foc TR4 and is mediated by the JA and ET signaling pathways, and not the SA pathway ( $\mathrm{Li}$ et al. 2012). Role of JA in banana defense is supported by another study reported by Sun et al. (2013) who showed that MeJA treatment dramatically reduced the disease incidence and disease severity of Foc4-infected banana plants compared to control and observed that MeJA treatment has triggered key enzymes of secondary metabolite biosynthetic pathways. Also Li et al. (2013a) found that both Focl and Foc TR4 infections led to similar gene expression profiles in banana roots where majorly ethylene synthetic genes like ACC oxidase and ethylene signaling pathways were found to be activated. These current studies suggest that banana defense against Foc is signaled mainly by JA and ethylene.

Several mutational studies have explored the signal transduction network controlling Fusarium oxysporum infection in Arabidopsis and tomato. Arabidopsis resistance to $F$. oxysporum f.sp. conglutinans and $F$. oxysporum f.sp. lycopersici was studied at different stages of signaling using mutants defective in the ET (ein2-5), JA (col-1 and jar1-1) and SA (NahG, sid2-1, eds5-1, npr1-1, pad41, eds1-1) (Berrocal-Lobo and Molina 2004) pathways, revealing the influence of these pathways against Fox. Thatcher et al. (2009), have demonstrated JA perception mutant coronatine insensitive 1 (coil), but not JA biosynthesis mutants, which exhibited a high level of resistance to wilt disease caused by $F$. oxysporum in Arabidopsis 
thaliana. Recently a novel transcription factor, LBD20 (Lateral Organ Boundaries Domain) gene which on its disruption led to increased resistance in Arabidopsis to Fox was found and this suggests that $L B D 20$ is a Fusarium susceptibility gene that appears to regulate components of JA-signaling downstream of COI1 and MYC2 transcription factors (Thatcher et al. 2012a).

JA signaling has a dichotomous involvement in the Arabidopsis interaction with $F$. graminearum, contributing to the attenuation of SA signaling during the early stages of infection and promotion of defense against $F$. graminearum during later stages of infection (Makandar et al. 2010). Similarly in another study involving Arabidopsis, a complex interaction between SA/NPRI and JA signaling regulates basal resistance against Fusarium head blight (FHB), because exposure to MeJA vapors either prior to fungal inoculation or during the early stages of fungal infection attenuated AtNPRI-conferred FHB resistance suggesting that during the early stages of infection, JA signaling attenuates SA/NPRI-determined defense signaling (Makandar et al. 2012). These findings were proved against hemibiotrophic pathogen $F$. graminearum. When there is no evidence of necrotrophy during early stages of infection (Brown et al. 2010; Goswami and Kistler 2004), activation of SA signaling curtails $F$. graminearum infection and, during the later stages of interaction, JA-regulated defenses target the necrotrophic phase of the fungal life cycle.

Overall JA and ET contribute to the immune response against Foc; the function of the SA in the immune response is complex and varies depending on the host. The above evidences conclude lesser role of SA against necrotrophic pathogens like Fox. Also on the ambiguous role of SA, Rahman et al. (2012) reported that necrotrophic pathogens use the salicylic acid signaling pathway to promote disease development in tomato, despite that some studies have reported that SA helps in defense response in general against necrotrophs suggesting that its role depends on the nature of host and pathogen, which needs thorough investigation (Dihazi et al. 2011; Amel et al. 2010). In case of banana, because of insufficient evidences, one cannot rule out SA role against Foc. It may play a role by interacting with JA to regulate the defense mechanism. This needs to be examined in light of hormone crosstalks in signaling.

\section{Calcium signaling}

One of the targets of ROS is the activation of $\mathrm{Ca}^{2+}$ permeable channels in plant membranes. $\mathrm{Ca}^{2+}$ has been proposed as important signaling molecule playing role as an intracellular secondary messenger in plants under various abiotic stresses, but few studies have explored its importance under biotic stress also (Blume et al. 2000; Lecourieux et al. 2002). Cyclic nucleotide-gated channels (CNGCs)$\mathrm{Ca}^{2+}$ influx has been studied in Arabidopsis, which showed that this influx is mediated by CNGC 2 , CNGC 4 , CNGC 11 and CNGC 12 after elicitor perception (Urquhart et al. 2011). But in Musa, it was found that CNGC 1, CNGC 5 and CNGC 6 changed after PAMP perception, which suggested that there is a fundamental difference in the $\mathrm{Ca}^{2+}$ influx mechanism between banana and Arabidopsis ( $\mathrm{Li}$ et al. 2012).

Calcineurin B-Like Proteins (CBLs) specifically target a family of protein kinases referred to as CIPKs (CBL-Interacting Protein Kinases). Several studies (Kobayashi et al. 2007; Kurusu et al. 2010) have demonstrated that CBLCIPK system produce ROS against elicitors (TvX/EIX). However, there were no studies on CBL-CIPK involvement specifically against Fox till date.

\section{G proteins}

G proteins are another important player in the resistance to necrotrophic fungi proteins (Llorente et al. 2005; Trusov et al. 2006, 2007). Heterotrimeric G proteins are GTPases composed of $\alpha, \beta, \gamma$ subunits, found as universal signal transduction elements in all eukaryotic organisms. The effects of the G $\beta$ (subunit deficiency in the mutant agbl2) on pathogenesis-related gene expression, as well as its genetic interaction with other mutants of established defense pathways were analyzed and proposed that G $\beta$ mediated resistance to Fox was mostly independent of JA, ET and ABA-mediated signaling pathways (Trusov et al. 2009). In Arabidopsis, G $\beta$ and G $\gamma 1$-deficient mutants (agb1-1, agb1-2, agg1-1 and agg1-2) displayed increased susceptibility to Fox (Perfus-Barbeoch et al. 2004).

\section{ABA}

ABA signaling, in addition to regulating plant development and response to abiotic stress, also plays a role in the regulation of innate immunity. ABA signaling as defense response is widely studied only in Arabidopsis; however, information against Fusarium infection is still fragmentary, whereas against other pathogens it has been widely studied. In Arabidopsis, by meta-analysis of pathogen-induced genes, activation of a significant set of ABA-regulated genes has been observed (Adie and Perez-Perez 2007). The positive regulatory function of ABA signaling in Arabidopsis innate immunity is supported by the enhanced resistance to several pathogens (e.g., Ralstonia solanacearum and necrotrophic pathogens) of the secondary cell wall mutant ern1/irx1 (Hernandez-Blanco et al. 2007). Also in some plant-pathogen interactions, ABA seems to play a 
negative regulatory function by inactivating other defense signaling pathways, such as those mediated by SA or JA/ ET (Anderson et al. 2004; Takahashi et al. 2004). Other examples for this negative function were observed between tomato and Erwinia chrysanthemi (Asselbergh et al. 2008), or Arabidopsis with the necrotrophic fungi Botrytis cinerea (Abuqamar et al. 2006).

Negative function of ABA has demonstrated Arabidopsis-Fox interaction. The aba2-1 mutant, which is impaired in ABA biosynthesis, shows an increased resistance to Fox; moreover, the jin1-9/myc2 mutants, which are impaired in the MYC2 transcriptional factor, a positive regulator of ABA signaling and a negative regulator of JA response, showed an increased resistance to Fox (Anderson et al. 2004; Lorenzo et al. 2003). Hence, as a defense role ABA has both positive and negative functions depending on the pathogen. A few studies on Arabidopsis-Fox interaction have shown negative function but to our knowledge there is no study on the ABA role in Foc infection in banana.

\section{Auxin}

Various studies suggest that auxin takes part in abiotic and biotic stress signaling pathways (Dowd et al. 2004; Navarro et al. 2006; Wang et al. 2007). The interaction of auxin with other hormones such as SA and JA in mediating plant defense responses has also been reported (Wang et al. 2007; Kazan and Manners 2008). Arabidopsis auxin signaling mutants axrl, axr2, and axr6 that have defects in the auxin-stimulated SCF (Skp1-Cullin-F-box) ubiquitination pathway exhibit increased susceptibility to the necrotrophic fungi Plectosphaerella cucumerina and Botrytis cinerea (Llorente et al. 2008). Upon Fusarium oxysporum f.sp. vasinfectum infection differential expression of auxinresponsive genes was revealed in cotton (Dowd et al. 2004). Recently it has been reported that Arabidopsis mutants with altered auxin and tryptophan-derived metabolites such as indole-glucosinolates and camalexin did not show an altered resistance to $F$. oxysporum. In contrast, several auxin-signaling mutants were more resistant to $F$. oxysporum which suggests that $F$. oxysporum requires components of auxin signaling and transport to colonize the plant more effectively (Kidd et al. 2011). Hence, focusing on the role of auxin in banana defense response in future will help to understand the resistant mechanism against Foc.

A few studies have proved the role of cell wall strengthening genes and ROS scavenging enzymes against Foc infection, but information on the signal transduction mechanism which gives the complete picture of defense mechanism is necessary. Receptor-like kinases (RLKs) in plants comprise a large family of proteins with potential cell surface signaling capacity (Shiu and Bleecker 2003;
Torii 2004) and where most of the defense genes belong to kinase group. Recent whole genome sequence of banana (D'Hont et al. 2012) revealed that there are $\sim 1,400$ protein kinases in the Musa genome. They are the largest kinase subgroup in plants and can be further divided into 12 subfamilies. The RLK/Pelle group was well documented in rice and has been shown to be involved in defense/resistance against pathogens. It has been identified that in Musa genome, the RLK/Pelle group contains 833 genes, but has not been studied much as in rice. In future, their roles in recognition, signal transduction and in developmental processes can be investigated to reveal the mechanism of defense response of banana against Foc.

Recently there are emerging studies on another class of receptor-like kinases called FERONIA (FER) family RLKs, which helps in cell growth regulation and also mediating resistance to pathogen attack. In flowering plants, signaling between the male pollen tube and the synergid cells of the female gametophyte is required for fertilization. In the Arabidopsis thaliana mutant feronia ( $f e r)$, fertilization is impaired; the pollen tube fails to arrest and thus continues to grow inside the female gametophyte (Escobar-Restrepo et al. 2007). But a study has shown that pollen tube reception and powdery mildew (PM) infection (which involves communication between a tip-growing hypha and a plant epidermal cell) share the molecular components, FER. It has been revealed that mutation in FERONIA (FER), a CrRLK, leads to spontaneous $\mathrm{H}_{2} \mathrm{O}_{2}$ production and cell death, resulting in PM resistance and aberrant pollen tube reception (Kessler et al. 2010). Interaction of another related RLK, At2g23200 in yeast two-hybrid assays with the Pseudomonas syringae effector AvrPto showed that its expression was regulated by a number of PAMPs, pathogen-secreted molecules that regulate infection and triggers immunity (Xiang et al. 2008). ANXUR 1 and ANXUR 2 which are RLKs help in cell wall integrity and are homologous to FER, but have opposite functions to FER (Boisson-Dernier et al. 2009; Miyazaki et al. 2009). These studies imply a dynamic signaling complex involving FER and ANXUR. Also Duan et al. (2010) group has found that mutant, At3g51550 encoding the FERONIA (FER) receptor-like kinase, induced severe root hair defects. They strongly support that FER acts as an upstream regulator for the RAC/ROP (RHO GTPase family)-signaled pathway that controls ROS-mediated root hair development. The interface for plant-pathogen interaction is the place where first battle starts between pathogens and the host cell. Therefore, FER could serve as a sensor of cell wall changes in plant induced by pathogen and in turn trigger downstream defense responses in the host cell. In the Banana Genome Hub database, around ten loci of FER were found which are present on the chromosomes namely, $\mathrm{Chr} 3,8,9,10$, 
11 and ChrUn_random (Droc et al. 2013). Fox invasion is through roots and as FERONIA also helps in root hair development as discussed, its interaction and involvement in signaling in banana during pathogen infection as observed in the case of powdery mildew will open a new area and help to understand the communication among ROS, FER and other unknown components. So far identified signaling compounds/genes are restricted to Arabidopsis and tomato plants, which need to be further elucidated in banana. To expand our understanding of complex signaling pathways in banana, efforts need to be taken to employ high throughput approaches such as transcriptome analysis, proteomic analysis and also reverse and forward genetics in banana.

\section{Fungal defense}

The fungal pathogen also has evolved strategies to invade plant and overcome the defense response of plants. Dissecting fungal infection strategies may help to evolve disease controlling strategies. In this regard, intensive research is being carried out on the pathogen. The fungus has to cross the plant cuticle and cell wall barriers for colonization and infection. The initial mechanism of invasion for fungus is to attack plant using CWDEs such as cellulases, polygalacturonases, xylanases, and proteinases, etc. These cell wall fragments act as elicitors which elicit defense reactions in host including the production of ROS and the secretion of antifungal proteins (D'Ovidio et al. 2004), such as PR proteins and inhibitor proteins (PGIP, XIP, etc.). Apart from CWDEs, recent studies have revealed various effector proteins and signal transduction components like mitogen-activated protein (MAP) kinases that play a possible role in the disease-causing mechanism. Also various toxins produced by Fox are being identified which causes pathogenicity of the host. Fusaric acid is the known toxin to be produced by various Fusarium species and one of the toxins responsible for wilt symptoms (Davis 1969). The toxin induces early super polarization of cell membrane (Fakhouri et al. 2003), capable of conjugating with $\mathrm{Cu}, \mathrm{Co}, \mathrm{Fe}$ and $\mathrm{Zn}$, forming chelates which make these minerals unavailable to plants (Chakrabarti and Ghosal 1989), leading to changes in membrane permeability and provokes production of ROS. In banana, the recent study investigated by Li et al. (2013c) has found the contamination of banana fruits from infected plant with toxins such as fusaric acid (FA) and beauvericin (BEA) suggesting that they contribute to the pathogenicity of the fungus during infection of banana plants. There is a great advancement in identification of pathogenicity genes of Fox but recent progress regarding the role of effector proteins alone is highlighted below.
In Fol, 11 (candidate) effector proteins (termed SIX) have been identified, which are recognized by I proteins (R-genes) of tomato (Takken and Rep 2010). Recently, homologs of $F$. oxysporum f.sp. lycopersici SIX1, SIX4, SIX8, and SIX9 have been identified in the genome of Fo5176 isolate that infects Arabidopsis. A SIX4 homolog (termed Fo5176-SIX4) differed from that of $F$. oxysporum f.sp. lycopersici (Fol-SIX4) by only two amino acids. Its induced expression during infection in Arabidopsis was observed (Thatcher et al. 2012b).

Forty percent of $\mathrm{Fol}$ genome assembly which are represented as $\mathrm{Fol}$ lineage-specific ( $\mathrm{Fol}$ LS) regions (comprises entire chromosomes of $3,6,14,15$, parts of chromosome 1 and 2 and most of the small scaffolds) are enriched for genes related to host-pathogen interactions. Significantly presence of genes involved in lipid metabolism and lipidderived secondary messengers in $\mathrm{Fol} \mathrm{LS}$ regions indicate an important role for lipid signaling in fungal pathogenicity. Genes of secreted proteins, Six 1 found to interact with Avr3 and Six 3 that interact with Avr2 were found to be located in LS regions (chromosome 14). Also genome data enabled the identification of genes for three additional proteins on chromosome 14, named as SIX5, SIX6 and SIX7 (Ma et al. 2010). Recently homologs of three Foc pathogenicity genes, SIX genes called SIXI, SIX7 and SIX8 were identified by Meldrum et al. (2012). Insertional mutant banks of Fol generated by inserting the novel modified impala element (fungal transposon) can be used for further investigation of pathogenicity genes (Lopez-Berges et al. 2009).

There is always competition for increasing fitness called 'arms race' between pathogen and host plants. Hundreds of fungal pathogenicity genes are being identified. Van De Wouw and Howlett (2011) have highlighted the databases that describe general fungal pathogenicity genes. But resistance can be overcome by mutations in the effectors leading to the infection and development of disease. Hence, genetic changes that enhance fitness, e.g., the ability to avoid host detection or regain pathogen recognition ability, will be maintained in the population (Maor and Shirasu 2005; Stahl and Bishop 2000). Ma et al. (2010) demonstrated that transfer of LS chromosome 14 between strains of $F$. oxysporum convert a non-pathogenic strain into a pathogen. This alarms the possibility of arrival of new strains in the future. Hence, it is always necessary to identify the coevolving proteins in host and pathogen to develop sustainable crop improvement strategies.

\section{Breeding/biotechnological aspects of developing tolerant cultivars}

Currently practiced measures to control fusarium wilt are application of fungicides and biological agents which 
controls the fungus partially. Identification of new cultivars by breeding resistance to Fox remains the most promising option. However, identification of resistant cultivars needs a thorough screening method which is the most critical aspect of breeding. Generally practiced technique to evaluate fusarium wilt tolerance, by screening the genotypes after artificial inoculation, is time consuming and sometimes susceptible plants have a chance to escape detection (Burger et al. 2003) due to various other factors. Thus, molecular approach has led the way to identify molecular markers tightly linked to fusarium wilt resistance genes that are highly valued in breeding.

The strategy of identifying dominant and recessive genes for resistance to fusarium wilt and their implication in breeding hybrids was studied in pigeonpea (Saxena et al. 2012). Map-based cloning and characterization of the resistance gene Fom-2 of melon conferring resistance to race 0 and 1 was done by Joobeur et al. (2004). Two InDel markers flanking to FOC (resistance gene to Fusarium oxysporum f.sp. conglutinans) which is linked to fusarium wilt resistance were developed in cabbage by $\mathrm{Lv}$ et al. (2013). There are studies that reported SCAR markers linked to Fox resistance in melon (Brotman et al. 2005), cotton (Wang et al. 2009), ginger (Swetha and Subramanian 2008), chickpea (Sharma et al. 2004) and eggplant (Mutlu et al. 2008). SCAR markers associated with resistance to Foc4 were developed by Wang et al. (2010) for banana, namely ScaU1001 and ScaS0901 which amplified in Foc4-resistant banana genotypes but not in susceptible genotypes tested. Inheritance of resistance in Musa to Foc race1 was also investigated. It was reported that resistance to fusarium wilt in Musa diploid hybrid conditioned by a single recessive gene called panama disease $1(P d l)$ can be used in recurrent selection breeding strategy (Ssali et al. 2013). The identified SCAR markers and QTLs linked to fusarium wilt resistance mostly correspond to resistance genes that may play major role in recognition. Hence where the genome sequence is available, studies should be carried out in future to characterize genes involved in defense mechanism pathways.

Some dessert banana hybrids are available which are developed at FHIA through conventional breeding that are resistant to fusarium wilt disease. FHIA-1 (AAB Pome type) and FHIA-17 (Gros Michel), Cavendish type are important which are being promoted for large-scale cultivation (http://www.promusa.org). Also other banana hybrids/populations developed at other centers like IITA, CIRAD and IIHR with fusarium resistance are available. Apart from conventional breeding somaclonal variation is also an effective strategy which has been used to improve the various horticultural traits. GCTCV-218, a giant Cavendish somaclonal variant with fusarium wilt resistance, was registered for commercial cultivation under the name
Formosona (Hwang 2002). Other somaclonal variants of Cavendish namely GCTCV-53 and GCTCV-119 identified, which showed resistance to fusarium wilt (Hwang and Ko 2004), has given the hopes to improve the crop using this technique which is faster than conventional breeding in banana. Mutagenesis has been established as an efficient tool for forward and reverse genetic approaches and plant breeding (Ahloowalia et al. 2004; Henikoff et al. 2004). However, it is a complex process to employ in vegetatively propagated plants. Jankowicz-Cieslak et al. (2012) group has developed a method by treating banana shoot apical meristems with the chemical mutagen ethyl methanesulphonate and recovered high density of GC-AT transition mutations showing that mutant genotypes are stably inherited in subsequent generations. They suggest that it therefore provides genotypic insights into the fate of totipotent cells after mutagenesis and suggests rapid approaches for mutation-based functional genomics and improvement of vegetatively propagated crops. Also five fusarium wiltresistant lines of banana from Brazil (Musa spp., AAA) were identified by field testing after in vitro mutagenesis using ethyl methanesulphonate (EMS) (Chen et al. 2013). Hence, we can adopt different breeding techniques for the improvement of banana.

\section{Transgenics and cisgenics approaches}

Transgenic approach is another efficient strategy for the development of fungal resistance in economically important fruit crops like banana. The majority of transgenic crops in trials are based on antimicrobial proteins for bacteria and fungi (Collinge et al. 2010). Genetically modified (GM) crops will be an effective solution to improve tolerance and balance the yields under changing climate and ever increasing human population. However, an attempt to develop resistant GM cultivars against $F O c$ has been initiated recently. Various genes (transgenes) that have been utilized to combat the fusarium wilt disease are listed in the Table 3.

Petunia floral defensins, PhDefl and PhDef2 (antimicrobial protein), were over expressed in transgenic banana plants using embryogenic cells as explants for Agrobacterium-mediated genetic transformation. High-level constitutive expression of these defensins in elite banana cv. Rasthali led to significant resistance against infection of Foc as shown by in vitro and ex vivo bioassay studies (Ghag et al. 2012). In another study, onion-derived gene encoding antimicrobial protein (Ace-AMP1) was introduced and expressed in transgenic banana (Mohandas et al. 2013). Mahdavi et al. (2012) have demonstrated that expression of rice thaumatin-like protein gene in transgenic banana plants showed enhanced resistance to Foc race 4. Apoptosis-like features in host plant are observed against necrotrophic 
Table 3 Candidate genes used for transgenic disease resistance against Fox

\begin{tabular}{|c|c|c|}
\hline Gene & Crop & References \\
\hline Defensin & Tomato & Abdallah et al. (2010) \\
\hline Glycosyl transferase & Flax & $\begin{array}{l}\text { Lorenc-Kukula et al. } \\
\text { (2009) }\end{array}$ \\
\hline Thionin & Arabidopsis & Epple et al. (1997) \\
\hline Antimicrobial peptide & Pepper & Lee et al. (2008) \\
\hline Defensin & Banana & Ghag et al. (2012) \\
\hline Thaumatin-like protein & Banana & Mahdavi et al. (2012) \\
\hline $\begin{array}{l}\text { B cell lymphoma-2 3'UTR } \\
\text { (Bcl-2 3'UTR) }\end{array}$ & Banana & Paul et al. (2011) \\
\hline Antimicrobial peptide & Banana & Mohandas et al. (2013) \\
\hline $\begin{array}{l}\text { Xylem sap protein } \\
\text { (silencing) }\end{array}$ & Tomato & Krasikov et al. (2011) \\
\hline
\end{tabular}

pathogens, where the pathogen feeds the dead tissue and increases its potential to grow fast. Hence, transgenic expression of apoptosis-inhibition-related animal genes that negatively regulate apoptosis, namely $B c l-x L, C e d-$ 9 and $\mathrm{Bcl}-23^{\prime}$ UTR, was tried in banana cultivar, 'Lady Finger'. Among these with over expression $\mathrm{Bcl}-23^{\prime}$ UTR line showed resistance to fusarium wilt (Paul et al. 2011). RNAi-based strategy for banana resistance using dsRNAs of adenylate cyclase, DNA polymerase alpha and delta subunits against $F o c$ spores in vitro displayed varying degrees of inhibition of spore germination (Mumbanza et al. 2013). This RNAi strategy may be adopted to generate transgenic plants resistance to Foc.

Cisgenesis can be an alternate strategy which involves using genes only from the same species or from its close relative which are crossable. Cisgenesis is an efficient method for cross-fertilizing heterozygous plants that propagate vegetatively, like banana. Conventional breeding also introduces new genes but due to linkage drag it leads to transfer of unwanted traits; hence cisgenic approach can make genetically modified crops more acceptable to public. For protecting crop against Foc, researchers have started exploring cisgenesis approaches to transfer resistance genes from cooking banana to dessert banana, both having a history of consumption, to protect against fusarium wilt (European Food Safety Authority 2012). Plants are known to contain hundreds of R genes (Sanseverino et al. 2010), where the molecular characterization of those genes from diverse species has revealed its specificity which can be utilized for cisgenic approaches to improve crop varieties in a convenient way. Wild banana species Musa balbisiana are found to be resistant to fusarium wilt and abiotic stresses. Hence, the genes/QTLs identified may be compatible with the existing cultivars. It may also provide additional desirable characters like tolerance to other biotic and abiotic stresses. The above strategies will help to protect the crop from fusarium wilt and overcome the constraints of routine chemical crop protection measures.

\section{Conclusion}

With the advance in plant molecular biology, we are able to understand defense mechanisms operating in the plant. Arabidopsis is still being used as a model to understand the defense mechanisms. The understanding of mechanism of Fox perception by the host is still rudimentary, although some potential pathogen receptors like RFOl in Arabidopsis, $I$ loci in tomato have been identified and studied. In case of banana several R-genes have been isolated, but detailed study about any specific R-genes contributing to virulence against specific target of $F o c$ has not been identified. Fungal infection enhances production of ROS and synthesis of peroxidases and PR proteins, leading to activation of several defense pathways.

Among them, pathways mediated by SA, JA, ET and ABA to play an important role in the modulation and networking of Arabidopsis innate immune response. There are several studies which support the major role of SA in defense mechanism, but recent reports show that JA plays a vital role in case of banana and in general against necrotrophs. As the molecular studies of banana-Foc interaction are still in the preliminary stage, we need to generate additional information to reveal the molecular mechanism controlling the mutually antagonistic or cooperative interactions between these signaling pathways. Depending on the stress, timing and magnitude of gene expression some signaling pathways are dominant over others and they are finely tuned by positive and negative regulation by different components of the pathway. The whole genome sequence of banana genotype, DH-Pahang, which is resistant to the new broad-range Fusarium oxysporum race 4 pathogen may form a valuable information for crop improvement in future. Breeding programs have successfully developed resistant genotypes against fusarium wilt in different crops but the emergence of new races of pathogen necessitates understanding host-pathogen interaction. Information on Fusarium virulent proteins is being generated. In the future, studies needs to be concentrated to identify and reveal the mechanism of their complementary molecular components in the host. Even though transgenic technology presents exciting possibilities, cisgenesis technology involving the transfer of gene from crossable/related species can be used safely and efficiently.

Acknowledgments The authors acknowledge financial support from Indian Council of Agricultural Research (ICAR), New Delhi through Network Project on Transgenics in Crops; Functional Genomics of Fusarium Wilt and Drought tolerance in banana. 


\section{References}

Abdallah NA, Shah D, Abbas D, Madkour M (2010) Stable integration and expression of a plant defensin in tomato confers resistance to fusarium wilt. GM Crops 1:344-350

Abuqamar S, Chen X, Dhawan R, Bluhm B, Salmeron J, Lam S, Dietrich RA, Mengiste T (2006) Expression profiling and mutant analysis reveals complex regulatory networks involved in Arabidopsis response to Botrytis infection. Plant $\mathrm{J} 48$ : 28-44

Adie BAT, Perez-Perez J (2007) ABA is an essential signal for plant resistance to pathogens affecting JA biosynthesis and the activation of defenses in Arabidopsis. Plant Cell 19:1665-1681

Ahloowalia BS, Maluszynski M, Nichterlein K (2004) Global impact of mutation-derived varieties. Euphytica 135:187-204

Amel AH, Soad MA, Ahmed AI (2010) Activation of tomato plant defense response against fusarium wilt disease using Trichoderma harzianum and salicylic acid under greenhouse conditions. Res J Agric Biol Sci 6:328-338

Anderson JP, Badruzsaufari E, Schenk PM, Manners JM, Desmond OJ, Ehlert C, Maclean DJ, Ebert PR, Kazan K (2004) Antagonistic interaction between abscisic acid and jasmonate-ethylene signaling pathways modulates defense gene expression and disease resistance in Arabidopsis. Plant Cell 16:3460-3479

Asselbergh B, Achuo AE, Hofte M, Gijsegem FN (2008) Abscisic acid deficiency leads to rapid activation of tomato defence responses upon infection with Erwinia chrysanthemi. Mol Plant Pathol 9:11-24

Bancroft J (1876) Report of the board appointed to enquire into the cause of disease affecting livestock and plants. In: Votes and proceedings 1877, Queensland

Bechinger C, Giebel KF, Schnell M, Leiderer P, Deising HB, Bastmeyer M (1999) Optical measurements of invasive forces exerted by appressoria of a plant pathogenic fungus. Science 285:1896-1899

Berrocal-Lobo M, Molina A (2004) Ethylene response factor 1 mediates Arabidopsis resistance to the soilborne fungus Fusarium oxysporum. Mol Plant Microbe Interact 17:763-770

Berrocal-Lobo M, Molina A (2007) Arabidopsis defense response against Fusarium oxysporum. Trends Plant Sci 13:145-150

Blume D, Nurnberger T, Nass N, Scheel D (2000) Receptor-mediated increase in cytoplasmic free calcium required for activation of pathogen defense in parsley. Plant Cell 12:1425-1440

Boisson-Dernier A, Roy S, Kritsas K, Grobei MA, Jaciubek M, Schroeder JI, Grossniklaus U (2009) Disruption of the pollen expressed FERONIA homologs ANXUR1 and ANXUR2 triggers pollen tube discharge. Development 136:3279-3288

Bolter C, Brammall RA, Cohen R, Lazarovits G (1993) Glutathione alterations in melon and tomato roots following treatment with chemicals which induce disease resistance to fusarium wilt. Physiol Mol Plant Pathol 42:321-336

Brotman Y, Kovalski I, Dogimon TC, Pitrat M, Portnoy V, PerlTreves NKR (2005) Molecular markers linked to papaya ring spot virus resistance and Fusarium race 2 resistance in melon. Theor Appl Genet 110:337-345

Brown NA, Urban M, van de Meene AML, Hammond-Kosack KE (2010) The infection biology of Fusarium graminearum: defining the pathways of spikelet to spikelet colonisation in wheat ears. Fungal Biol 114:555-571

Burger Y, Katzir N, Tzuri G, Portnoy V, Saar U, Shriber S, PerlTreves R, Cohen R (2003) Variation in the response of melon genotypes to Fusarium oxysporum f.sp. melonis race 1 determined by inoculation tests and molecular markers. Plant Pathol 52:204-211

Butler D (2013) Fungus threatens top banana. Nature 504:195
Chakrabarti DK, Ghosal S (1989) The disease cycle of mango malformation induced by Fusarium moniliforme var. subglutinans and the curative effects of mangiferin-metal chelates. J Phytopathol 125:238-246

Chen YF, Chen W, Huang X, Hu X, Zhao JT, Gong Q, Li XJ, Huang XL (2013) Fusarium wilt-resistant lines of Brazil banana (Musa spp., AAA) obtained by EMS-induced mutation in a microcrosssection cultural system. Plant Pathol 62:112-119

Clematis F, Tedeschini J, Dolci M, Lanzotti V, Cangelosi B, Fascella S, Curir P (2011) Phenol Composition and Susceptibility to Fusarium oxysporum dianthi in Carnation. J Life Sci 5: 921-925

Cole SJ, Diener AC (2013) Diversity in receptor-like kinase genes is a major determinant of quantitative resistance to Fusarium oxysporum f.sp. matthioli. New Phytol 200:172-184

Collinge DB, Jorgensen HJ, Lund OS, Lyngkjaer MF (2010) Engineering pathogen resistance in crop plants: current trends and future. Annu Rev Phytopathol 48:269-291

D'Hont A, Denoeud F, Aury JM, Baurens FC, Carreel F, Garsmeur O, Noel B, Bocs S et al (2012) The banana (Musa acuminata) genome and the evolution of monocotyledonous plants. Nature 488:213-217

D’Ovidio R, Mattei B, Roberti S, Bellincampi D (2004) Polygalacturonases, polygalacturonase-inhibiting proteins and pectic oligomers in plant-pathogen interactions. Biochim Biophys Acta 1696:237-244

Dangl JL, Jones JDG (2001) Plant pathogens and integrated defense responses to infection. Nature 411:826-833

Davis D (1969) Fusaric acid in selective pathogenicity of Fusarium oxysporum. Phytopathology 59:1391-1395

De Ascensao ARFDC, Dubery IA (2003) Soluble and wall-bound phenolics and phenolic polymers in Musa acuminata roots exposed to elicitors from Fusarium oxysporum f.sp. cubense. Phytochemistry 63:679-686

De Lorenzo G, D'Ovidio R, Cervone F (2001) The role of polygalacturonase-inhibiting proteins (PGIPs) in defense against pathogenic fungi. Annu Rev Phytopathol 39:313-335

Delledonne M, Zeier J, Marocco A, Lamb C (2001) Signal interactions between nitric oxide and reactive oxygen intermediates in the plant hypersensitive disease resistance response. Proc Natl Acad Sci USA 98:13454-13459

Deslandes L, Olivier J, Peeters N, Feng DX, Khounlotham M, Boucher C, Somssich I, Genin S, Marco Y (2003) Physical interaction between RRS1-R, a protein conferring resistance to bacterial wilt, and PopP2, a type III effector targeted to the plant nucleus. Proc Natl Acad Sci USA 100:8024-8029

Di C, Zhang M, Xu S, Cheng T, An L (2006) Role of poly-galacturonase inhibiting protein in plant defense. Crit Rev Microbiol 32:91-100

Diener AC, Ausubel FM (2005) RESISTANCE TO FUSARIUM OXYSPORUM 1, a dominant Arabidopsis disease-resistance gene, is not race specific. Genetics 171:305-321

Dihazi A, Serghini MA, Jaiti F, Daayf F, Driouich A, Dihazi H, Hadrami IE (2011) Structural and biochemical changes in salicylic-acid-treated date palm roots challenged with Fusarium oxysporum f. sp. Albedinis. J Pathog. doi:10.4061/2011/280481

Dita MA, Waalwij C, Buddenhagen IW, Souza MT Jr, Kema GHJ (2010) A molecular diagnostic for tropical race 4 of the banana fusarium wilt pathogen. Plant Pathol 59:348-357

Dong X, Ling N, Wang M, Shen Q, Guo S (2012) Fusaric acid is a crucial factor in the disturbance of leaf water imbalance in Fusarium-infected banana plants. Plant Physiol Biochem 21:171-179

Dowd C, Wilson IW, McFadden H (2004) Gene expression profile changes in cotton root and hypocotyl tissues in response to 
infection with Fusarium oxysporum f. sp. vasinfectum. Mol Plant Microbe Interact 17:654-667

Droc G, Lariviere D, Guignon V, Yahiaoui N, This D, Garsmeur O. Dereeper A, Hamelin C, Argout X, Dufayard JF et al (2013) The banana genome hub. Database (Oxford) 2013:bat035

Duan Q, Kita D, Li C, Cheung AY, Wu HM (2010) FERONIA receptor-like kinase regulates RHO GTPase signaling of root hair development. Proc Natl Acad Sci USA 107:17821-17826

Durrant WE, Dong X (2004) Systemic acquired resistance. Annu Rev Phytopathol 42:185-209

Edgar CI, McGrath KC, Dombrecht B, Manners JM, Maclean DJ, Schenk PMP, Kazan K (2006) Salicylic acid mediates resistance to the vascular wilt pathogen Fusarium oxysporum in the model host Arabidopsis thaliana. Australas Plant Pathol 356:581-591

EFSA Panel on Genetically Modified Organisms (GMO) (2012) Scientific opinion addressing the safety assessment of plants developed through cisgenesis and intragenesis. EFSA J 10(2):2561. doi:10.2903/j.efsa.2012.2561

Enciso-Rodriguez FE, Gonzale C, Rodriguez EA, Lopez CE, Landsman D, Luz Stella Barrero LS, Marino-Ramirez L (2013) Identification of immunity related genes to study the Physalis peruviana-Fusarium oxysporum pathosystem. PLoS One 8(7):e68500. doi:10.1371/journal.pone.0068500

Endah R, Beyene G, Kiggundu A, Van den Berg N, Schluter U, Kunert K, Chikwamba R (2008) Elicitor and Fusarium-induced expression of NPR1-like genes in banana. Plant Physiol Biochem 46:1007-1014

Epple P, Apel K, Bohlmann H (1997) Overexpression of an endogenous thionin enhances resistance of Arabidopsis against Fusarium oxysporum. Plant Cell 9:509-520

Escobar-Restrepo JM, Huck N, Kessler S, Gagliardini V, Gheyselinck $\mathrm{J}$ et al (2007) The FERONIA receptor-like kinase mediates male-female interactions during pollen tube reception. Science 317:656-660

Fakhouri W, Walker F, Armbruster W, Buchenauer H (2003) Detoxification of fusaric acid by a nonpathogenic Colletotrichum sp. Physiol Mol Plant Pathol 63:263-269

Farag Hanaa RM, Zeinab AA, Dawlat AS, Mervat ARI, Sror HAM (2011) Effect of neem and willow aqueous extracts on fusarium wilt disease in tomato seedling: 1-induction of antioxidant defensive enzymes. Arab Univ J Agric Sci 19:131-140

Fourie G, Steenkamp ET, Gordon TR, Viljoen A (2009) Evolutionary relationships among the Fusarium oxysporum f.sp. cubense vegetative compatibility groups. Appl Environ Microbiol 75:4470-4781

Fraser RSS (1990) The genetics of plant-virus interactions: mechanisms controlling host range, resistance and virulence. In: Recognition and response in plant-virus interactions. NATO ASI series, cell biology, vol 41, pp 71-91

Garcia-Limones C, Dorado G, Navas-Cortes JA, Jimenez-Diaz RM, Tena M (2009) Changes in the redox status of chickpea roots in response to infection by Fusarium oxysporum f. sp. ciceris: apoplastic antioxidant enzyme activities and expression of oxidative stress-related genes. Plant Biol 11:194-203

Geiser DM, Del Mar Jimenez-Gasco M, Kang S, Makalowska I, Veeraraghavan N, Ward TJZN, Zhang N, Gretchen A, Kuldau GA, Donnell KO (2004) FUSARIUM-ID v. 1.0: a DNA sequence database for identifying Fusarium. Eur J Plant Pathol 110:473-479

Ghag SB, Shekhawat UKS, Ganapathi TR (2012) Petunia floral defensins with unique prodomains as novel candidates for development of fusarium wilt resistance in transgenic banana plants. PLoS One 7:e39557

Goswami RS, Kistler HC (2004) Heading for disaster: Fusarium graminearum on cereal crops. Mol Plant Pathol 5:515-525
Groenewald S, Van den Berg N, Marasus WFO, Altus V (2006) The application of high-throughput AFLP's in assessing genetic diversity in Fusarium oxysporum f. sp. cubense. Mycol Res 110:297-305

Henikoff S, Till BJ, Comai L (2004) TILLING. Traditional mutagenesis meets functional genomics. Plant Physiol 135:630-636

Hermanto C, Sutanto A, Jumjunidang, Edison HS, Daniells JW, O’Neil WT, Sinohin VGO, Molina AB, Taylor P (2011) Incidence and distribution of Fusarium wilt disease of banana in Indonesia. Acta Hortic 897:313-322

Hernandez-Blanco C, Dong Xin Feng DX, Hu J, Sanchez-Vallet A, Deslandes L, Llorente F, Berrocal-Lobo M, Harald Keller H, Barlet X, Sanchez-Rodriguez C, Anderson LK, Somerville S, Marco Y, Molina A (2007) Impairment of cellulose synthases required for Arabidopsis secondary cell wall formation enhances disease resistance. Plant Cell 19:890-903

Houterman PM, Cornelissen BJ, Rep M (2008) Suppression of plant resistance gene-based immunity by a fungal effector. PLoS Pathog 4:e1000061

Huckelhoven R (2007) Cell wall-associated mechanisms of disease resistance and susceptibility. Annu Rev Phytopathol 45:101-127

Hwang SC (2002) FORMOSANA: a new Cavendish variety with super high yield and fusarium wilt resistance selected by somaclonal variation. TBRI, Taiwan

Hwang SC, Ko WH (2004) Cavendish banana cultivars resistant to fusarium wilt acquired through somaclonal variation in Taiwan. Plant Dis 88:580-588

Ingle A, Ingle R (2013) Isolation and Identification of Fusarium oxysporum infecting Musa plants in Maharashtra region and their molecular characterization. Asiat J Biotech Res 4:28-34

Jankowicz-Cieslak J, Huynh OA, Brozynska M, Nakitandwe J, Till BJ (2012) Induction, rapid fixation and retention of mutations in vegetatively propagated banana. Plant Biotechnol J 10:1056-1066

Jimenez-Gasco MM, Navas-Cortes JA, Jimenez-Diaz RM (2004) The Fusarium oxysporum f. sp. ciceris/Cicer arietinum pathosystem: a case study of the evolution of plant-pathogenic fungi into races and pathotypes. Int Microbiol 7:95-104

Jin X, Feng D, Wang H, Wang J (2007) A novel tissue-specific plantain beta-1,3-glucanase gene that is regulated in response to infection by Fusarium oxysporum f.sp. cubense. Biotechnol Lett 29:1431-1437

Jongedijk E, Tigelaar H, Van Roekel JSC, Bres-Vloemans SA, Dekker I, Van den Elzen PJM, Ben JC, Cornelissen BJC, Melchers LS (1995) Synergistic activity of chitinases and $\beta$-1,3-glucanases enhances fungal resistance in transgenic tomato plants. Euphytica 85:173-180

Joobeur T, King JJ, Nolin SJ, Thomas CE, Dean RA (2004) The fusarium wilt resistance locus Fom-2 of melon contains a single resistance gene with complex features. Plant J 39:283-297

Kavino M, Kumar N, Damodaran T, Harish S, Saravanakumar D (2007) Biochemical markers as a useful tool for the early identification of Fusarium oxysporum f.sp. cubense, race1 resistance banana clones. Arch Phytopathol Plant Prot 42:1069-1078

Kazan K, Manners JM (2008) Jasmonate signaling: toward an integrated view. Plant Physiol 146:1459-1468

Kessler SA, Shimosato-Asano H, Keinath NF, Wuest SE, Ingram G, Panstruga R, Grossniklaus U (2010) Conserved molecular components for pollen tube reception and fungal invasion. Science 12:968-971

Kidd BN, Kadoo NY, Dombrecht B, Tekeoglu M, Gardiner DM, Thatcher LF, Aitken EAB, Schenk PM, Manners JM, Kazan K (2011) Auxin signaling and transport promote susceptibility to the root-infecting fungal pathogen Fusarium oxysporum in Arabidopsis. Mol Plant Microbe Interact 24:733-748 
Kobayashi M, Ohura I, Kawakita K, Yokota N, Fujiwara M, Shimamoto K, Doke N, Yoshioka H (2007) Calcium-dependent protein kinases regulate the production of reactive oxygen species by potato NADPH oxidase. Plant Cell 19:1065-1080

Krasikov V, Dekker HL, Rep M, Takken FL (2011) The tomato xylem sap protein XSP10 is required for full susceptibility to fusarium wilt disease. J Exp Bot 62:963-973

Kunkel BN, Brooks DM (2002) Cross talk between signaling pathways in pathogen defense. Curr Opin Plant Biol 5:325-331

Kurusu T, Hamada J, Nokajima H, Kitagawa Y, Kiyoduka M, Takahashi A, Hanamata S, Ohno R, Hayashi T, Okada K, Koga J, Hirochika H, Yamane H, Kuchitsu K (2010) Regulation of microbe-associated molecular pattern-induced hypersensitive cell death, phytoalexin production, and defense gene expression by calcineurin B-like protein-interacting protein kinases, OsCIPK14/15, in rice-cultured cells. Plant Physiol 153:678-692

Lecourieux D, Mazars C, Pauly N, Ranjeva R, Pugin A (2002) Analysis and effects of cytosolic free calcium increases in response to elicitors in Nicotiana plumbaginifolia cells. Plant Cell 14:2627-2641

Lee SC, Hwang IS, Choi HW, Hwang BK (2008) Involvement of the pepper antimicrobial protein CaAMP1 gene in broad spectrum disease resistance. Plant Physiol 148:1004-1020

Leong SK, Latiffah Z, Baharuddin S (2010) Genetic diversity of Fusarium oxysporum f. sp. cubense isolates from Malaysia. Afr J Microbiol Res 4:1026-1037

Li MH, Yang B, Leng Y, Chao CP, Liu JM, He ZF, Jiang ZD, Zhong $S$ (2011a) Molecular characterization of Fusarium oxysporum f. sp. cubense race 1 and 4 isolates from Taiwan and Southern China. Can J Plant Pathol 33:168-178

Li C, Chen S, Zuo C, Sun Q, Ye Q, Yi G, Huang B (2011b) The use of GFP-transformed isolates to study infection of banana with Fusarium oxysporum f. sp. cubense race 4. Eur J Plant Pathol 131:327-340

Li WM, Qian CM, Mo YW, Hu YL, Xie JH (2011c) Tolerance of banana for fusarium wilt is associated with early $\mathrm{H}_{2} \mathrm{O}_{2}$ accumulation in the roots. Afr J Biotechnol 10:11378-11387

Li CY, Deng GM, Yang J, Viljoen A, Jin Y, Kuang RB, Zuo CW, Lv ZC, Yang QS, Sheng O, Wei YR, Hu CH, Dong T, Yi GJ (2012) Transcriptome profiling of resistant and susceptible Cavendish banana roots following inoculation with Fusarium oxysporum $\mathrm{f}$. sp. cubense tropical race 4. BMC Genomics 13:374

Li C, Shao J, Wang Y, Li W, Guo D, Yan B, Xia Y, Peng M (2013a) Analysis of banana transcriptome and global gene expression profiles in banana roots in response to infection by race 1 and tropical race 4 of Fusarium oxysporum f. sp. cubense. BMC Genomics 14:851

Li X, Bai T, Li Y, Ruan X, Li H (2013b) Proteomic analysis of Fusarium oxysporum f. sp. cubense tropical race 4-inoculated response to Fusarium wilts in the banana root cells. Proteome Sci 11:41

Li C, Zuo C, Deng G, Kuang R, Yang Q et al (2013c) Contamination of bananas with beauvericin and fusaric acid produced by Fusarium oxysporum f. sp. cubense. PLoS One 8(7):e70226

Lievens B, Rep M, Thomma BP (2008) Recent developments in the molecular discrimination of formae speciales of Fusarium oxysporum. Pest Manag Sci 64:781-788

Llorente F, Alonso-Blanco C, Sanchez-Rodriguez C, Jorda L, Molina A (2005) ERECTA receptor-like kinase and heterotrimeric $\mathrm{G}$ protein from Arabidopsis are required for resistance to the necrotrophic fungus Plectosphaerella cucumerina. Plant J 43:165-180

Llorente F, Muskett P, Sanchez-Vallet A, Lopez G, Ramos B, Sanchez-Rodriguez C, Jorda L, Parker J, Molina A (2008) Repression of the auxin response pathway increases Arabidopsis susceptibility to necrotrophic fungi. Mol Plant 1:496-509
Lopez-Berges MS, Di Pietro A, Daboussi MJ, Wahab HA, Vasnier C, Roncero MIG, Dufresne M, Hera C (2009) Identification of virulence genes in Fusarium oxysporum f. sp. lycopersici by largescale transposon tagging. Mol Plant Pathol 10:95-107

Lorenc-Kukuła K, Zuk M, Kulma A, Czemplik M, Kostyn K, Skala J, Starzycki M, Szopa J (2009) Engineering flax with the GT family 1 Solanum sogarandinum glycosyltransferase SsGT1 confers increased resistance to Fusarium infection. J Agric Food Chem 57:6698-6705

Lorenzo O, Piqueras R, Sanchez-Serrano JJ, Solano R (2003) ETHYLENE RESPONSE FACTOR1 integrates signals from ethylene and jasmonate pathways in plant defense. Plant Cell $15: 165-178$

Lu Y, Liao D, Pu J, Qi Y, Xie Y (2013) Proteome analysis of resistant and susceptible Cavendish banana roots following inoculation with Fusarium oxysporum f.sp. cubense. Physiol Mol Plant Pathol 84:163-171

Lv H, Yang L, Kang J, Wang Q, Wang X, Fang Z, Liu Y, Zhuang M, Zhang Y et al (2013) Development of InDel markers linked to Fusarium wilt resistance in cabbage. Mol Breed 32:961-967

Ma LJ, van der Does HC, Borkovich KA, Coleman JJ, Daboussi MJ, Di Pietro A, Dufresne M, Freitag M et al (2010) Comparative genomics reveals mobile pathogenicity chromosomes in Fusarium. Nature 464:367-373

Mahdavi F, Sariah M, Maziah M (2012) Expression of rice thaumatin-like protein gene in transgenic banana plants enhances resistance to fusarium wilt. Appl Biochem Biotechnol 166:1008-1019

Makandar R, Nalam V, Chaturvedi R, Jeannotte R, Sparks AA, Shah J (2010) Involvement of salicylate and jasmonate signaling pathways in Arabidopsis interaction with Fusarium graminearum. Mol Plant Microbe Interact 23:861-870

Makandar R, Nalam VJ, Lee H, Trick HN, Dong Y, Shah J (2012) Salicylic acid regulates basal resistance to fusarium head blight in wheat. Mol Plant Microbe Interact 25:431-439

Mandal S, Mitra A, Mallick N (2008) Biochemical characterization of oxidative burst during interaction between Solanum lycopersicum and Fusarium oxysporum f. sp. lycopersici. Physiol Mol Plant Pathol 72:56-61

Maor R, Shirasu K (2005) The arms race continues: battle strategies between plants and fungal pathogens. Curr Opin Microbiol 8:399-404

Maziah M, Sariah M, Sreeramanan S (2007) Transgenic banana Rastali (AAB) with $\beta$-1, 3-glucanase gene for tolerance to Fusarium wilt race 1 disease via Agrobacterium-mediated transformation system. Plant Pathol J 6:271-282

McGrath KC, Dombrecht B, Manners JM, Schenk PM, Edgar CI, Maclean DJ, Scheible WR, Udvardi MK, Kazan K (2005) Repressor- and activator-type ethylene response factors functioning in jasmonate signaling and disease resistance identified via a genome-wide screen of Arabidopsis transcription factor gene expression. Plant Physiol 139:949-959

Meldrum RA, Fraser-Smith S, Tran-Nguyen LTT, Daly AM, Aitken EAB (2012) Presence of putative pathogenicity genes in isolates of Fusarium oxysporum f. sp. cubense from Australia. Australas Plant Pathol 41:551-557

Miller RNG, Bertioli DJ, Baurens FC, Santos CMR, Alves PC, Martins NF, Togawa RC, Souza MT (2008) Analysis of non-TIR NBS-LRR resistance gene analogs in Musa acuminata Colla: isolation, RFLP marker development, and physical mapping. BMC Plant Biol 8:15

Mittler R, Vanderauwera S, Gollery M, Van Breusegem F (2004) The reactive oxygen gene network in plants. Trends Plant Sci 9:490-498

Miyazaki S, Murata T, Sakurai-Ozato N, Kubo M, Demura T, Fukuda H, Hasebe M (2009) ANXUR1 and 2, sister genes to 
FERONIA/SIRENE, are male factors to coordinated fertilization. Curr Opin 19:1327-1331

Mohamed MA, Shousha WG, Mahdy EM, Ghazy AM, Mohamed MM (2007) Biochemical Alterations induced in tomato in response to Fusarium oxysporum infection: purification and characterization of an acidic $\alpha-1,3$-glucanase. Res J Agric Biol Sci 3:939-949

Mohandas S, Sowmya HD, Saxena AK, Meenakshia S, Thilaka Rania R, Mahmood Riaz (2013) Transgenic banana cv. Rasthali (AAB, Silk gp) harboring Ace-AMP1 gene imparts enhanced resistance to Fusarium oxysporum f.sp. cubense race 1. Sci Hortic 164:392-399

Molina AB, Fabregar EG, Sinohin V, Fourie G, Viljoen A (2008) Tropical race 4 of Fusarium oxysporum f. sp. cubense causing new Panama wilt epidemics in Cavendish varieties in the Philippines. Phytopathology 98(Suppl.):S108

Moore NY, Bentley S, Pegg KG, Jones DR (1995) Fusarium wilt of banana, Musa disease fact sheet, vol 5. International Network for the Improvement of Banana and Plantain, Montpellier, pp $1-4$

Mumbanza FM, Kiggundu A, Tusiime G, Tushemereirwe WK, Niblett C, Bailey A (2013) In vitro antifungal activity of synthetic dsRNA molecules against two pathogens of banana, Fusarium oxysporum f. sp. cubense and Mycosphaerella fijiensis. Pest Manag Sci 69:1155-1162

Mustaffa MM, Thangavelu R (2011) Status of Fusarium wilt in India. Acta Hortic 897:323-328

Mutlu N, Boyaci FH, Gocmen M, Abak K (2008) Development of SRAP, SRAP-RGA, RAPD and SCAR markers linked with a Fusarium wilt resistance gene in eggplant. Theor Appl Genet 117:1303-1312

Navarro L, Dunoyer P, Jay F, Arnold B, Dharmasiri N, Estelle M et al (2006) A plant miRNA contributes to antibacterial resistance by repressing auxin signaling. Science 312:436-439

Onate-Sanchez L, Anderson JP, Young J, Singh KB (2007) AtERF14, a member of the ERF family of transcription factors, plays a non redundant role in plant defense. Plant Physiol 143:400-409

Paul JY, Becker DK, Dickman MB, Harding RM, Khanna HK, Dale JL (2011) Apoptosis-related genes confer resistance to Fusarium wilt in transgenic 'Lady Finger' bananas. Plant Biotechnol J 9:1141-1148

Peraza-Echeverria S, Dale JM, Harding RM, Smith MK, Chris Collet C (2008) Characterization of disease resistance gene candidates of the nucleotide binding site (NBS) type from banana and correlation of a transcriptional polymorphism with resistance to Fusarium oxysporum f.sp. cubense race 4. Mol Breed 22:565-579

Perez-Vicente L (2004) Fusarium wilt (Panama disease) of bananas: an updating review of the current knowledge on the disease and its causal agent. Publication Especial. XV1 Reunion International Acrobat 2004. Dexaca, Mexico, pp 1-15

Perfus-Barbeoch L, Jones AM, Assmann SM (2004) Plant heterotrimeric $\mathrm{G}$ protein function: insights from Arabidopsis and rice mutants. Curr Opin Plant Biol 7:719-731

Pieterse CMJ, Dicke M (2007) Plant interactions with microbes and insects: from molecular mechanisms to ecology. Trends Plant Sci $12: 564-569$

Ploetz RC (2005) Panama disease, an old nemesis rears its ugly head: Part 1, the beginnings of the banana export trades. Online Plant Health Prog. doi:10.1094/PHP-2005-1221-01-RV. http://www.apsnet.org/online/feature/panama/

Rahman TAE, Elom EOM, Gonzalez-Lamothe R, Bouarab K (2012) Necrotrophic pathogens use the salicylic acid signaling pathway to promote disease development in tomato. Mol Plant Microbe Interact 25:1584-1593
Rathod PJ, Vakharia DN (2011) Biochemical changes in chickpea caused by Fusarium oxysporium f. sp. ciceri. Int J Plant Physiol Biochem 3:195-204

Ravishankar KV, Rekha A, Swarupa V, Savitha G (2011) Gene expression analysis in roots of Musa acuminata ssp. burmannicoides 'Calcutta-4', a banana genotype tolerant to Fusarium wilt. Acta Hortic 897:363-370

Rep M, van der Does HC, Meijer M, van Wijk R, Houterman PM, Dekker HL, de Koster CG, Cornelissen BJC (2004) A small, cysteine-rich protein secreted by Fusarium oxysporum during colonization of xylem vessels is required for I-3-mediated resistance in tomato. Mol Microbiol 53:1373-1383

Salehzadeh A (2012) Interaction of polygalacturonase enzymes from Fusarium oxysporum with tomato polygalacturonase inhibiting protein. Afric J Agric Res 7:2012-2015

Sanseverino W, Roma G, De Simone M, Faino L, Melito S, Stupka E, Frusciante L, Ercolano MR (2010) PRGdb: a bioinformatics platform for plant resistance gene analysis. Nucleic Acids Res 38:814-821

Saxena KB, Kumar RV, Saxena RK, Sharma M, Srivastava RK, Sultana R, Varshney RK, Vales MI, Pande S (2012) Identification of dominant and recessive genes for resistance to Fusarium wilt in pigeonpea and their implication in breeding hybrids. Euphytica 188:221-227

Schippers B, Van Eck WH (1981) Formation and survival of chlamydospores in Fusarium. In: Nelson PE, Tousson TA, Cook RJ (eds) Fusarium: disease, biology, and taxonomy. Penn State University Press, University Park, pp 250-260

Sharma KD, Winter P, Kahl G, Muehlbauer FJ (2004) Molecular mapping of Fusarium oxysporum f. sp. ciceris race 3 resistance gene in chickpea. Theor Appl Genet 108:1243-1248

Shiu SH, Bleecker AB (2003) Expansion of the receptor-like kinase/Pelle gene family and receptor-like proteins in Arabidopsis. Plant Physiol 132:530-543

Ssali RT, Kiggundu A, Lorenzen J, Karamura E, Tushemereirwe W, Viljoen A (2013) Inheritance of resistance to Fusarium oxysporum f. sp. cubense race 1 in bananas. Euphytica. doi:10.1007/ s10681-013-0971-6

Stahl EA, Bishop JG (2000) Plant-pathogen arms races at the molecular level. Curr Opin Plant Biol 3:299-304

Sun D, Lu X, Hu Y, Li W, Hong K, Mo Y, Cahill DM, Xie J (2013) Methyl jasmonate induced defense responses increase resistance to Fusarium oxysporum f. sp. cubense race 4 in banana. Sci Hortic 164:484-491

Swarupa V, Ravishankar KV, Rekha A (2013) Characterization of tolerance to Fusarium oxysporum f.sp., cubense infection in banana using suppression subtractive hybridization and gene expression analysis. Physiol Mol Plant Pathol 83:1-7

Swetha PR, Subramanian RB (2008) Isolation and molecular analysis of R-gene in resistant Zingiber officinale (ginger) varieties against Fusarium oxysporum f. sp. zingiberi. Bioresour Technol 99:4540-4543

Tada Y, Mori T, Shinogi T, Yao N, Takahashi S, Betsuyaku S, Sakamoto M, Park P, Nakayashiki H, Tosa Y, Mayama S (2004) Nitric oxide and reactive oxygen species do not elicit hypersensitive cell death but induce apoptosis in the adjacent cells during the defense response of oat. Mol Plant Microbe Interact 17:245-253

Takahashi H, Kanayama Y, Zheng MS, Kusano T, Hase S, Ikegami M, Shah J (2004) Antagonistic interactions between the SA and JA signaling pathways in Arabidopsis modulate expression of defense genes and gene-for-gene resistance to cucumber mosaic virus. Plant Cell Physiol 45:803-809

Takken F, Rep M (2010) The arms race between tomato and Fusarium oxysporum Mol. Plant Pathol 11:309-314 
Thatcher LF, Manners JM, Kazan K (2009) Fusarium oxysporum hijacks COI1-mediated jasmonate signaling to promote disease development in Arabidopsis. Plant J 58:927-939

Thatcher LF, Powell JJ, Aitken EAB, Kazan K, Manners JM (2012a) The Lateral Organ Boundaries Domain transcription factor LBD20 functions in Fusarium wilt susceptibility and jasmonate signaling in Arabidopsis. Plant Physiol 160:407-418

Thatcher LF, Gardiner DM, Kazan K, Manners JM (2012b) A highly conserved effector in Fusarium oxysporum is required for full virulence on Arabidopsis. Mol Plant Microbe Interact 25:180-190

Torii KU (2004) Leucine-rich repeat receptor kinases in plants: structure, function, and signal transduction pathways. Int Rev Cytol 234:1-46

Torres MA, Jones JDG, Dangl JL (2006) Reactive oxygen species signaling in response to pathogens. Plant Physiol 141: 373-378

Trusov Y, Rookes JE, Chakravorty D, Armour D, Schenk PM, Botella JR (2006) Heterotrimeric G-proteins facilitate Arabidopsis resistance to necrotrophic pathogens and are involved in jasmonate signaling. Plant Physiol 140:210-220

Trusov Y, Rookes JE, Tilbrook K, Chakravorty D, Mason MG, Anderson D, Chen JG, Jones AM, Botella JR (2007) Heterotrimeric G protein $\gamma$ subunits provide functional selectivity in $\mathrm{G} \beta \gamma$ dimer signaling in Arabidopsis. Plant Cell 19:1235-1250

Trusov Y, Sewelam N, Rookes JE, Kunkel M, Nowak E, Schenk PM, Botella JR (2009) Heterotrimeric G proteins-mediated resistance to necrotrophic pathogens includes mechanisms independent of salicylic acid-, jasmonic acid/ethylene- and abscisic acidmediated defense signaling. Plant J 58:69-81

Urquhart W, Chin K, Ung H, Moeder W, Yoshioka K (2011) The cyclic nucleotide-gated channels AtCNGC11 and 12 are involved in multiple $\mathrm{Ca}^{2+}$-dependent physiological responses and act in a synergistic manner. J Exp Bot 62:3671-3682

Van De Wouw AP, Howlett BJ (2011) Fungal pathogenicity genes in the age of 'omics'. Mol Plant Pathol 12:507-514
Van den Berg N, Berger DK, Hein I, Birch PRJ, Wingfield MJ, Viljoen A (2007) Tolerance in banana to Fusarium wilt is associated with early up-regulation of cell wall-strengthening genes in the roots. Mol Plant Pathol 8:333-341

Venkatesh Krishna V, Kumar KG, Pradeepa K, Kumar SR, Kumar RS (2013) Biochemical markers assisted screening of Fusarium wilt resistant Musa paradisiaca (L.) cv. puttabale micropropagated clones. Indian J Exp Biol 51:531-542

Wang D, Pajerowska-Mukhtar K, Culler AH, Dong X (2007) Salicylic acid inhibits pathogen growth in plants through repression of the auxin signaling pathway. Curr Biol 17:1784-1790

Wang PZ, Su L, Qin L, Hu B, Guo WZ, Zhang TZ (2009) Identification and molecular mapping of a Fusarium wilt resistant gene in upland cotton. Theor Appl Genet 119:733-739

Wang W, Hu Y, Sun D, Staehelin C, Xin D, Xie J (2010) Identification and evaluation of two diagnostic markers linked to Fusarium wilt resistance (race 4) in banana (Musa spp.). Mol Biol Rep 39:451-459

Wolter M, Hollricher K, Salamini F, Schulze-Lefert P (1993) The mlo resistance alleles to powdery mildew infection in barley trigger a developmentally controlled defence mimic phenotype. Mol Gen Genet 239:122-128

Xiang T, Zong N, Zou Y, Wu Y, Zhang J, Xing W, Li Y, Tang X, Zhu L, Chai J, Zhou JM (2008) Pseudomonas syringae effector AvrPto blocks innate immunity by targeting receptor kinases. Curr Biol 18:74-80

Yao N, Imai S, Tada Y, Nakayashiki H, Tosa Y, Park P, Mayama S (2002) Apoptotic cell death is a common response to pathogen attack in oats. Mol Plant Microbe Interact 15:1000-1007

Zhu QH, Stephen S, Kazan K, Jin G, Fan L, Taylor J, Dennis ES, Helliwell CA, Wang MB (2013) Characterization of the defense transcriptome responsive to Fusarium oxysporum-infection in Arabidopsis using RNA-seq. Gene 512:259-266

Zvirin T, Herman R, Brotman Y (2010) Differential colonization and defence responses of resistant and susceptible melon lines infected by Fusarium oxysporum race 1.2. Plant Pathol 59:576-585 